Discussion Paper Series A No.610

\title{
Redistributive Effects of Income Tax Rates and \\ Tax Base 1984-2009: \\ Evidence from Japanese Tax Reforms
}

\author{
Takeshi Miyazaki \\ (Department of Economics, Kyushu University) \\ and \\ Yukinobu Kitamura \\ (Institute of Economics Research, Hitotsubashi University)
}

June, 2014

Institute of Economic Research

Hitotsubashi University

Kunitachi, Tokyo, 186-8603 Japan 


\title{
Redistributive Effects of Income Tax Rates and Tax Base 1984-2009: Evidence from Japanese Tax Reforms
}

\author{
Takeshi Miyazaki $^{1}$ and Yukinobu Kitamura ${ }^{2}$ \\ Department of Economics, Kyushu University, Fukuoka, Japan \\ 6-19-1 Hakozaki Higashiku, Fukuoka 812-8581, Japan \\ Institute of Economic Research, Hitotsubashi University, Tokyo, Japan
}

\begin{abstract}
The primary objective of this paper is to examine how, and to what extent, changes in income tax rates and income tax deductions affect income inequality from a longitudinal perspective, by using microdata of Japanese individuals and households. The findings of this paper could shed light on the effects of tax rates and tax deductions on tax progressivity. First, redistributive effects of Japanese income tax reforms declined for the period from 1984-2009. Second, the tax reforms with reductions in tax rates and in tax base gave rise to greater redistributive effects of income tax rates and smaller redistributive effects of tax base. Third, any progressivity measure and approach to determine pretax income showed the same trends, with respect to the redistributive effects of tax reforms.
\end{abstract}

Keywords: Income taxation, redistribution, tax deduction, tax rate JEL classification: D3, H2, H24

\footnotetext{
1 Tel.: +81-(0)92-642-4272; fax: +81-(0)92-642-4272; e-mail: tmiyazak@econ.kyushu-u.ac.jp.

2 We would like to thank Minoru Hayashida and Masahiko Nakazawa and the seminar participants at Kyushu University and the 2014 Japanese Economic Association Spring Meeting at Doshisha University for their helpful comments. This work was supported by the Joint Usage and Research Center, Institute of Economic Research, Hitotsubashi University.
} 


\section{Introduction}

Numerous researchers have conducted empirical studies to investigate the redistributive effects of income taxation across countries or year ranges, using microdata at an individual or household level (e.g., Bishop et al., 1997; Bishop, Formby, and Zheng, 1998; Dandanoni and Lambert, 2002; Kakwani, 1977; Kasten et al., 1994; Lambert, 2001; Lambert and Thorensen, 2009; Thorensen, 2004). It is well known that the tax reforms of the 1980s and the 1990s in the Organization for Economic Co-operation and Development (OECD) countries led to substantial cuts in marginal tax rates and changes in income tax deduction thresholds. Existing empirical studies have examined the relationship between taxation reforms in these periods and the redistribution through income taxes for Western countries, such as the United States (Bishop et al., 1997; Kasten et al., 1994), Norway (Lambert and Thorensen, 2009; Thorensen, 2004), Sweden, and the United Kingdom (Bishop et al., 1997). These studies found that the redistributive effects of personal income tax remained unchanged after tax reforms in the 1980s and the 1990s in Sweden, the UK, and the US, but decreased after the tax changes in the 1990s and the 2000s in Norway.

Incidentally, in the major tax reforms of 1987 and 1989 in Japan, there were large cuts in the marginal tax rates, particularly for those in the top income bracket, and an increase in income tax deductions (e.g., Ishi, 2001). In contrast to the case of Western countries, however, the redistribution effects of Japanese income tax reforms have rarely been examined using microdata at an individual or household level. ${ }^{3}$ Although there exist a small number of empirical works concerned with income redistribution in Japan, they have primarily focused on the trend of posttax income inequality and inequalities arising from intergenerational transfers between the young and the elderly (e.g., Fukawa and Oshio, 2007; Oshio, 2006). Further, to the best of our knowledge, the studies concerned with tax reforms in Western countries have not addressed how income tax rates and tax deductions individually influence a posttax income inequality.

The primary objective of this paper is to conduct a longitudinal study of how, and to what extent, changes in income tax rates and tax base affect income inequality, using microdata of Japanese individuals and households. We used data sourced from the

\footnotetext{
3 Exceptions are Kitamura and Miyazaki (2012, 2013), who examined the same microdata used in the current paper to determine to what extent Japanese tax reforms altered distributions of income and income inequality. However, they do not distinguish between the effects of tax rates and tax deductions.
} 
National Survey of Family Income and Expenditure (NSFIE) from 1984-2009, collected by the Ministry of Communication and Internal Affairs (MIC). We estimated the magnitude of redistribution caused by changes in tax rates and tax base by applying each year's tax law to earnings and computing income, taxable income, and after-tax income, taking into account household characteristics. The Reynolds-Smolensky (RS) and the Blackorby-Donaldson (BD) indices were employed as measures of inequality. Among progressivity measures that have been developed for substantial and strict evaluation of the progressivity of a tax system, the RS index is used to measure tax progressivity by comparing the distribution of pretax income to that of posttax income; that is, by observing the disparity in the income shares of taxpayers ranked by income. ${ }^{4}$ Pfahler (1990) and Lambert (2001) also showed that the RS index could be precisely decomposed into tax rate and tax base effects. Also, this sort of measure, based on quantile share information, relies on there being no-reranking of property, referring to the concentration coefficients of pretax incomes, with respect to posttax or taxable incomes. ${ }^{5}$ Under the Japanese personal income tax system, the no-reranking property does not hold because tax bases are determined by not only pretax incomes, but also by the demographic composition of households and incomes of the individuals in a family. We then developed the modified RS indices, which are redistributive measures, with respect to taxable and posttax incomes, in the form of Gini coefficients rather than concentration coefficients, to eliminate the influence of reranking. In contrast, the BD index is used to measure progressivity as the proportionate increase in equality, relative to the initial level of equality, based on social welfare functional reasoning. As both indices have a wide range of disparity in terms of evaluation of inequality, we used both of these indices.

Further, in assessing tax policies from an intertemporal perspective, it is of great interest to isolate the effects of tax policies to obtain a better understanding of the driving forces behind pre- and posttax income inequalities. As a way to determine pretax income, we adopted the "fixed income" approach, in which the distribution of pretax income in a base year is exposed to various tax laws in a given period, to keep income, characteristics of families, and demographic composition constant. However, the fixed

\footnotetext{
${ }_{4}$ Besides, there are many existing works concerned with the measurement of redistribution policies. Related to the present paper, Pechman and Okner (1974) evaluate inequality reduction as a percentage of pretax income, and Fellman et al (1999) measure inequality reducing performance of redistribution policy as the percentage of the maximum reduction scheme, yielding the same amount of tax.

5 Refer to Lambert (2001) and Cowell (2011) for an introduction to the concept of rerankings in relation to inequality measures.
} 
income approach has some drawbacks, such as instability in measurement of inequality (e.g., Lambert and Thorensen, 2009), so to improve the robustness of our results, we also adopted the transplant-and-compare (T-C) procedure developed by Dandanorni and Lambert (1992). The T-C procedure is a methodology to evaluate income distribution from a longitudinal viewpoint, under which a posttax distribution is compared to a common regime by correcting for any pretax distributional changes that may have occurred across periods.

The primary contribution of this study is our assessment of the redistributive impacts of income tax rates and tax base, using individual and household microdata. A number of empirical studies have attempted to find the association between tax reforms with declining progressivity and the redistributive effect of income taxation, by measuring the disparity of altered income distributions between pre- and posttax incomes (e.g., Bishop et al., 1997; Lambert and Thoresen, 2009; Thoresen, 2004). However, despite the fact that changes in tax deductions and tax rates, as seen in tax reforms in OECD countries in the 1980s and 1990s, are expected to have distinct effects on progressivity, no study has been aimed at distinguishing the redistributive effects of tax rates from those of the tax base, caused by tax reforms in the period. It seems that both wider tax deductions and lower tax rates in each income bracket have a negative impact on tax progressivity. It is, however, difficult to determine in advance the effects of such a seemingly low progressive tax reform on the redistributive effects of tax schedules, because these effects also depend on the shape of income distribution. For example, under a uniform income distribution, no redistributive effects are reported even if progressive tax schedules are applied. This paper explores the redistributive effects of tax rates and base distinctively, based on progressivity measurements such as the RS and BD indices. By including in our sample the major Japanese tax reforms over the period 1984-2009, which involved large variations in marginal tax rates and tax deductions, we ensured the robustness of calculations of tax progressivity.

Another contribution of this study is that we addressed the progressivity effects of tax rates and base from the various perspectives of tax progressive measures and pretax income definition. To attain consistent estimates of such measures, as stated above, we employed several progressivity measures and rectified these indices to take into account rerankings in the income distribution. In addition, to deal with variations in income distribution over time, which are likely to result in a false measurement of progressivity, we applied the fixed income approach, in which pretax income is fixed at the base year, 
to our household income data. From the perspective of longitudinal comparisons of the redistributive effects, we employed several base years for pretax incomes in the fixed income approach. The T-C method is also implemented to improve the robustness of results.

We obtained the following three main findings. First, the redistributive effects of Japanese personal income tax declined between 1984 and 2009. Some empirical studies found that the redistributive effects of personal income tax did not change after tax reforms in the 1980s and 1990s in OECD countries, including Sweden, the UK, and the US (Bishop et al., 1997; Kasten et al., 1994), but others stated that they did decrease after the tax changes in the 1990s and 2000s in Norway (Lambert and Thoresen, 2009; Thoresen, 2004; Thorensen et al., 2011). Japanese income tax reforms in the 1980s2000s led to lower redistributive effects on personal income taxes.

Second, reductions in tax rates and in tax base arising from income tax reforms gave rise to greater redistributive effects of income tax rates and lower redistributive effects of tax base. The reduced redistributive effects from changes in tax base are in line with the logic that a uniform tax base reduction for all taxpayers is associated with less progressivity. It is, however, a surprising result that during the periods 1984-1989 and 1994-2004, the redistributive effects of tax rates increased, despite the lower marginal tax rates for each income bracket resulting from the income tax reforms. This result can be attributed, in part, to the measurement of the equalizing effects of tax rates. As the effects are computed by comparing inequality measures of taxable income and posttax income, they rely on changes in tax base as well. Thus, the declining tax bases brought about more unequal taxable income distribution, with the redistributive effects of tax rates being more progressive. It can be inferred from this result that when assessing the progressive impacts of tax reforms in terms of tax rates and tax base using the Gini-based inequality measures, changes in tax base as well as those in tax rates influence progressivity. In addition, the regressive impacts of tax reforms are weakened by smaller marginal tax rates for low-income earners after the tax reforms and the less progressive property of income tax for high-income earners before the tax reforms, in the periods from 1984-1989 and 1994-1999.

Third, most progressivity measures and approaches to determine pretax income show identical trends with respect to the redistributive effects of tax reforms over the period. The evaluation of tax reforms, from the perspective of redistribution, is known to 
depend on the choice of inequality measures and the employed parameters for such measures, including Gini-based indices and the Atkinson inequality-based indices (e.g., Lambert and Thorensen, 2009). Moreover, the methods for determining pretax income and the selection of the base year income for the fixed income approach are closely related to tax progressivity outcomes (Kasten et al., 1994; Lambert and Thorensen, 2009). For this reason, we could demonstrate the reliability of our analysis if we obtained consistent results from several types of tax progressivity measures and definitions of pretax income. Our results from the RS index and the two BD indices for any approach to determine pretax income follow the same trends, although the amounts differ slightly. Therefore, it is found that the consequences attained could be consistent and reliable.

\section{Japanese Personal Income Taxation and Calculation of Incomes}

\subsection{Japanese Income Tax and Its Reforms}

In 1949, after World War II, the modern Japanese tax system was established by a tax mission headed by Carl S. Shoup, with the aim of establishing a stable and permanent tax system that centered direct taxes. One of the features of the Japanese tax system was that there was a strong reliance on direct taxes, mainly income taxes from individuals and corporations. In 1995, for example, 36.6\% of total tax revenues in Japan were collected from income taxes, which is smaller than that in the USA (45.8\%) and the UK (36.9\%) but larger than in other European countries including France (17.6\%) and Germany (30.1\%) (Ishi, 2000). ${ }^{6}$ This tendency toward heavy dependence on income taxes was stronger before 1990 because of the nonexistence of consumption taxes and greater tax burden on incomes. ${ }^{7}$ In recent years, the ratio of consumption taxes to total taxes has increased because of the increase in consumption tax rates and the declining tax burdens on individual and corporate income taxes. In the 1970s and the 1980s, issues such as bracket creep caused by inflation and horizontal inequality in taxation on interest receipts became apparent. To deal with these issues, the Japanese government conducted fundamental reforms of the tax system in 1987 and 1989.

Insert Figure 1 about here

\footnotetext{
${ }^{6}$ National and local taxes and social security contributions are included in the total tax revenue.

7 According to the Ministry of Finance (2000), in $199070.7 \%$ of total national tax revenue came from income taxes, compared with $60.5 \%$ in 1995 .
} 
The Japanese income tax reforms in the 1980s and the 1990s resulted in lessened marginal tax rates and increased tax deductions and exemptions, which causes a decline in the tax base. The tax reforms in other developed countries in the 1980s and the 1990s also rendered income tax rates lower than before. The income tax rates in every income bracket have been decreasing since the early 1980s, and those for the highest income bracket, in particular, have dropped considerably. In the 1980s, there was a criticism that high income tax rates relative to other developed countries caused deterioration in the economic efficiency of Japanese firms and individuals (e.g., Ishi, 2000). Furthermore, the inflation that had prevailed over developed counties-including Japan-in the 1980s raised a bracket creep problem, that is, an increase in income tax rates resulting from changes to the upper income tax bracket, via inflated nominal income. Figure 1 depicts marginal tax rates against taxable income for the every 5 years from 1984 to 2009. As can be seen, the top income tax rates decreased over the period except for 2009 and at the same time, to cope with the bracket creep problem, the width of each bracket was enlarged. ${ }^{8}$ In fact, one of the objectives of the tax reform was to widen the brackets for the medium income group to reduce the tax burdens stemming from bracket creep. When introducing the general consumption tax in 1989, the total income tax liabilities were reduced through declining income tax rates and increased tax deductions and exemptions, so the total tax burden for individuals remained unchanged. Meanwhile, in 2009, the tax rate scheme was further complicated because income tax rates were altered, following changes in rates of local taxes on personal income-called "personal inhabitant tax" —in Japan.

Insert Table 1 around here

Moreover, there was a significant increase in income tax deductions and exemptions from the 1980s to the early 2000s. Deductions of Japanese income tax mainly comprise casualty losses, medical expenses, social insurance premiums, life insurance premiums, fire and other casualty insurance premiums, earthquake insurance premiums, and donations. Exemptions comprise those for widows or widowers, working students, the disabled, dependents, spouses, special exemption for spouses, and basic exemption. ${ }^{9}$ In the 1980s and 1990s, the existing deductions and exemptions enlarged and new types of

\footnotetext{
8 After 1989 the number of brackets for each income tax rate fell from 12 notches to 5 .

9 Special exemption for spouses is aimed at lessening income tax liabilities for salaried workers who have a nonworking spouse. Part of the special exemption was abolished in 2004 because it was determined that it provided incentives for spouses not to work.
} 
deductions and exemptions were created to lessen income tax liabilities. During the fundamental tax reforms in 1987 and 1989, almost all deductions and exemptions that existed at the time-including basic exemption and exemptions for spouses, dependents, and the disabled-widened, and several exemptions-including those for the young (aged 16-22) and the elderly, and special exemption for spouses-were created. In addition, because the 1995 tax reform also raised tax exemptions, in the 1980s and the 1990s taxable income-defined as income after withholding deductions and exemptions, or tax base-greatly reduced. Key income tax deductions and exemptions are listed in Table 1. It demonstrates that the tax exemptions have widened from the first half of the 1980s to the late 1990s. In contrast, as shown in the table, the tax exemptions have tended to shrink from the early 2000s. This policy change reflected the tax reforms in this period, which were intended to mitigate women's disincentives to work and raise more income tax revenue by widening the tax base.

\subsection{Calculation of household income from microdata}

In this study we employed microdata of Japanese individuals and households from the National Survey of Family Income and Expenditure (NSFIE) provided by Ministry of Internal Affairs and Communication (MIC). ${ }^{10}$ The NSFIE is a sample-based survey conducted every five years, comprising information on earnings, marital status, sex, age, job, and type and status of employment. ${ }^{11}$ The demographic attributes are stored separately for each member of the household. The earnings of household members except for the head of the family and his/her spouse are aggregated as earnings for members aged 65 or over and those aged 64 or under. In some cases, it is difficult to match each member's attributes with their earnings on one-to-one level. Therefore, we matched as many members' demographic attributes and earnings as possible, and eliminated from the sample households in which members' incomes were not able to be precisely matched. ${ }^{12}$ The following earnings were included in the sample: salaries, ${ }^{13}$

\footnotetext{
10 The NSFIE comprises low income individuals when compared to other individual income microdata such as the Comprehensive Survey of Living Condition (CSLC) and the Survey on Income Distribution (SIR). Specifically, multiperson households with earnings lower than 2 million yen (approximately US $\$ 20,000$ ) represent only $3 \%$ of those included in the NSFIE and single-person households in that bracket represent 10\%, compared to $19 \%$ from the CSLC in 2004. This means that inequality measures of the market income from the NSFIE tend to be lower relative to those gained from CSLC. In effect, however, the measures from both microdata exhibit a similar downward trend.

11 Consumption of specific items and holding properties were also surveyed.

12 When matching the data, we made use of employment status data as well for identification purposes. For example, if only one employee aged 64 or under, or 65 or over exists in a household, then we were able to identify the source of earnings in the household.
} 
agriculture and fishery business, business other than agriculture and fishery, on-the-side jobs, pension and retired income, and housing and land rent. Earnings from interest and dividends were not taken into account because reports of these income sources are somewhat inaccurate in the NSFIE. We also excluded captive uses from agricultural and fishery products and owner-occupied house, because of difficulty in assessing of them. ${ }^{14}$

Each member's earnings, income, taxable income, and tax burdens were calculated for all households, according to the following steps. First, "income" is defined as earnings minus either costs (for business revenue) or deductions for salaries (for wage income). Employment income is income derived from salaries, wages, bonuses, and allowances. Second, taxable income is calculated by subtracting income tax deductions and exemptions from income. Tax deductions and exemptions taken into account in the current study include medical expenses, social insurance premiums, life insurance premiums, fire and other casualty insurance premiums, exemptions for working students, spouses, and dependents, special exemption for spouses, and basic exemption. ${ }^{15}$ Total deduction and exemption is determined by summing up amounts of deductions and exemptions for each household on the basis of the household's characteristics and tax laws of the corresponding fiscal year. Third, tax liabilities for the head of each household are calculated by multiplying taxable income by progressive income tax rates. In the light of the purpose of this study - that is, examining the redistributive effects of tax rates and tax base-tax credits were not calculated here. ${ }^{16}$

To accurately compare different sized households, income was measured using an equivalent scale. Taking into account economies of scale in households, household income was divided by the square root of the number of household members (including children). After-tax income and taxable income were also adjusted using an equivalent scale. Trends in earnings and income were adjusted by growth rate, calculated by dividing total annual earnings by the corresponding annual earnings in the standard

\footnotetext{
13 For employees, allowances for dependents and child benefits and housing benefits are included in salaries.

14 Several researchers do not contain imputed income from own-houses in calculation of income. Lambert and Thorensen (2009), for example, excluded from their sample taxable returns from housing investment owing to the issue of the undervaluation of imputed income from owner-occupied homes. Further, Bishop et al. (2004) used tax returns data for audited taxpayers without consideration of imputed rents from housing.

15 Deductions such as those for earthquake insurance premiums and donations, and exemptions for widows or widowers, and for the disabled, were excluded from calculation of income deduction and exemption, owing to inherent restrictions such as data availability and difficulty in measuring amounts of deduction and exemption.

${ }^{16}$ Local taxes for personal income are also not included in the tax liabilities.
} 
year. ${ }^{17}$ Meanwhile, in order to make the tax systems comparable across the various years, the same normalization was applied to the thresholds of income brackets and tax deductions and exemptions in each year.

\section{Measurement of the Redistributive Effects of Tax Rates and Base}

The current study calculates the Reynolds-Smolensky (RS) and the BlackorbyDonaldson (BD) indices, and then evaluates the equalizing effects of tax scheme, tax rates, and tax base. With regard to the decomposition of overall redistribution effects into rate and base effects, we use the methodology shown in Pfahler (1990) and Lambert (2001, ch. 8) to compute the contributions to progressivity of the tax rates and deductions. It is assumed that for each $p \in(0,1)$ there is just one pretax income $y$ with rank $p=F(y)$, where $F(y)$ is a distribution function of pretax income $x$. Because the Gini coefficient is a measure based on the Lorenz curve, Lorenz curves relating to this analysis are defined as:

$$
\begin{gathered}
p=F(y) \Rightarrow L_{X}(p)=\int_{0}^{y} \frac{x f(x) \mathrm{d} x}{\mu} \\
p=F_{X-T}(y-t) \Rightarrow L_{X-T}(p)=\int_{0}^{y-t} \frac{v f_{X-T}(v) \mathrm{d} v}{\mu(1-g)} \\
p=F_{X-D}(y-d) \Rightarrow L_{X-D}(p)=\int_{0}^{y-d} \frac{w f_{X-D}(w) \mathrm{d} w}{\mu(1-\delta)}
\end{gathered}
$$

where $f(x)$ is a density function, $\mu$ denotes mean pretax income, and $g$ denotes overall average tax rate. Then $L_{X}(p)$ indicates the Lorenz curve for pretax income. $F_{X-T}(v)$ and $f_{X-T}(v)$ are, respectively, the distribution and density functions of posttax income $v=x-t(x)$, and $L_{X-T}$ is the Lorenz curve for posttax income. The same argument holds for gross income net of deduction: That is, $F_{X-D}(w)$ and $f_{X-D}(w)$ are the distribution and density functions of the tax base $w=x-d(x) . \delta$ denotes the average rate of deduction $d / \mu$, and $L_{X-D}$ is the Lorenz curve for taxable income.

In what follows, the Gini coefficients for pretax income, posttax income, and income net of tax deduction can be expressed in terms of the Lorenz curves defined above:

$$
G_{X}=1-2 \int_{0}^{1} L(p) \mathrm{d} p
$$

17 The standard year is defined as 2004 in this study. 


$$
\begin{aligned}
& G_{X-T}=1-2 \int_{0}^{1} L_{X-T}(p) \mathrm{d} p, \\
& G_{X-D}=1-2 \int_{0}^{1} L_{X-D}(p) \mathrm{d} p,
\end{aligned}
$$

where $G_{X}$ represents the Gini coefficient for pretax income, $G_{X-T}$ the Gini coefficient for posttax income, and $G_{X-D}$ the Gini coefficient for income net of deduction. From the definition of the RS index, versions of the RS index in terms of tax burdens and tax deductions are expressed as:

$$
\begin{aligned}
& \Pi^{\mathrm{RS}}=G_{X}-G_{X-T}, \\
& \Pi_{R}^{\mathrm{RS}}=G_{X-D}-G_{X-T}, \\
& \Pi_{D}^{\mathrm{RS}}=G_{X}-G_{X-D},
\end{aligned}
$$

where $\Pi^{\mathrm{RS}}$ is the RS index that measures the redistributive effects of overall tax burdens on income inequality, taking into account reranking after taxation. $\Pi_{R}^{\mathrm{RS}}$ is the RS index that measures the redistributive effects of tax rates. $\Pi_{D}^{\mathrm{RS}}$ represents the progressivity of income tax in the light of changes in tax deductions. The definitions of these indicators slightly differ from those based on standard concentration coefficients because the Gini coefficients were adopted as the indices to measure distribution after changes in tax schemes.

As shown in Lambert (2001, ch. 8), usually the overall RS index is defined in terms of the separation of the coefficients $G_{X}$ and $C_{X-T}$, the concentration coefficient for posttax income, preserving the ranking of taxpayers equal to that in pretax distribution. However, the no reranking assumption does not hold for the Japanese income taxation, for deductions and exemptions are determined taking into account elements other than earnings, such as characteristics and income of household members. Therefore, to deal with this problem, in this study we quantified the equalizing effects of tax schedules in terms of its impact on the Gini coefficient, as shown above. Using such modified RS indices, the term capturing the negative contribution of reranking emerged as the difference between the Gini coefficient and the concentration coefficient for posttax income, which is expressed by $G_{X-T}-C_{X-T}$. We then evaluated the extent of the reranking effects by calculating the difference mentioned above, for every modified RS index. The reranking effects become positive by the definition of the concentration coefficients, as seen, for example, in Theorem 2.2 of Lambert (2001); larger reranking effects can be interpreted as frequent occurrence of reranking. It also seems that more rerankings arise from complicated tax schedules with tax liabilities being dependent on 
elements other than income.

The BD index proposed by Blackorby and Donaldson (1984) is also used in this analysis:

$$
\begin{aligned}
\Pi^{\mathrm{BD}}(e) & =\frac{I_{X}(e)-I_{X-T}(e)}{1-I_{X}(e)}, \\
\Pi_{R}^{\mathrm{BD}}(e) & =\frac{I_{X-D}(e)-I_{X-T}(e)}{1-I_{X-D}(e)}, \\
\Pi_{D}^{\mathrm{BD}}(e) & =\frac{I_{X}(e)-I_{X-D}(e)}{1-I_{X}(e)},
\end{aligned}
$$

where $I_{X}(e)$ represents the Atkinson index for pretax income, with a constant-inequality-aversion parameter $e . \Pi^{\mathrm{BD}}$ indicates the percentage increase in income equality stemming from overall tax reform, where equality is measured as (1 inequality). Equally, $\Pi_{D}^{\mathrm{BD}}$ and $\Pi_{D}^{\mathrm{BD}}$ indicate the percentage increase or decrease in equality caused by change in tax rates and change in tax base, respectively.

As stated in the literature, the degrees of changes in redistributional effects through tax reforms across time are not only explained by the tax reforms themselves, but also changes in income distribution (e.g., Lambert, 2001). Because income distribution is subject to income, consumption, family characteristics, and demographic composition in society, it is difficult to precisely evaluate the effects of tax reforms on posttax income distribution and tax progressivity by using the actual pretax income. To isolate the effects of tax policy changes alone, we adopted the fixed income approach proposed by Kasten et al. (1994). ${ }^{18}$ That is, we applied each year's tax law to a sample of families in a single year, to fix income, characteristics of families, and demographic composition.

The fixed income approach is considered better than that applied to actual incomes. It is, however, pointed out that the outcomes of this approach vary by the adopted base year of the income. Lambert and Thorensen (2009), for example, stated that the criterion that results should not be sensitive to the choice of the base year when applying a methodology in order to rank tax progressivity effects of tax schemes, means that the fixed income approach is not adequate for this sort of analysis. Instead, they proposed using a transplant-and-compare (T-C) procedure developed by Dardanoni and Lambert

18 Thorensen (2004) also applied the fixed income approach to explore the change in tax progressivity in Norway in the 1990s. 
(2002), in which posttax distribution is compared to a common regime by correcting for any pretax distributional changes that may have happened across the period. Lambert and Thorensen (2009) also mentioned that the fixed income approach yielded unreasonable results in the application for the Norwegian tax reform, and thus, is difficult to apply in the sense of requiring information with respect to tax changes. Therefore, we also applied the T-C procedure to the Japanese tax reforms in order to examine robustness of this analysis.

However, in this paper we mainly refer to the results found using the fixed income approach rather than those found using the T-C procedure from the following reasons. First, unlike the previous studies in which the T-C procedure was adopted, ${ }^{19}$ the pretax income distribution may not follow an isoelastic distribution, such as lognormal. As Lambert and Thorensen (2009) mentioned, the key assumption that has to be satisfied when the T-C procedure is applied is that the base pretax income distribution differs isoelastically from others only in location and scale, with regard to logarithms. For example, they regressed the log of the gross income of Norway in the base years-1992, 1998, and 2004 — on those in the remaining other years, and found that the goodness of fit of the regressions $\left(R^{2}\right)$ is significantly high, with the majority over 0.95 . In the current work, as can be seen below, less than one third of $R^{2}$ values for the regressions in each base year are over 0.95, and some of them are below 0.90, meaning that the assumption of isoelastic distribution is not satisfied. Second, some deficits in the fixed income approach do not apply to this analysis. Because we developed a calculation procedure for Japanese personal income tax schemes over every year, the application of the fixed income approach to our data is relatively easy. Moreover, using the fixed income approach we obtained an identical pattern of results from the income data of different base years, meaning that major concern with regard to this approach-the sensitivity of outcomes to the choice of the base year-did not arise in this case. It follows that while focusing more on the estimation results obtained by using the fixed income approach, we took into account the results from T-C procedure as well with the aim of determining more reliable implications of the progressivity effects of tax reforms.

\section{Data}

19 See, for instance, Lambert and Thorensen (2009) and Thorensen et al. (2011). 
Descriptive statistics and basic measures for income inequality from 1984 to 2009 are provided in Table 2. In terms of descriptive statistics, mean income changed only slightly during the period, but standard deviation increased by 35\%. Specifically, standard deviation rose rapidly in the period 1984 to 1989, during the implementation of the fundamental tax reform - a reduction in the tax rates for those in the top income bracket and enlargement of tax deduction. The same trends from an intertemporal perspective were observed with regard to inequality measures. Median income fell in this period, and there was a notable increase in inequality. In particular, the squared coefficient of variation (SCV), the Theil index (TI), and the two Atkinson indices (AI) increased by more than $80 \%$. Concerning the specific percentiles of income, P10 (proportion of the income at 10 percentail to the median income) declined but P90 (that at 90 percentail) increased, leading to an increase of P90/P10. These statistics reveal an increasing income inequality from 1984 to 2009.

Insert Tables 2, 3, and 4 about here

Table 3 presents the same statistics as Table 2, but in terms of taxable income. Similar to income, mean and median taxable incomes did not change in the period, but inequality measures increased, though less rapidly than income. Specifically, SCV, TI, and the two estimates of $\mathrm{AI}$ increased by more than $50 \%$. Because the growth rates of the median and the mean logarithmic deviation (MLD) are negative, the extent of the increasing inequality could possibly be weak for taxable income compared with income. Table 4 also shows the posttax income trends were close to those in Table 2 and 3 . That is, mean and median values for posttax income remained constant over the period, while inequality measures rose more sharply than income and taxable income. SCV, TI, and the two measures of AI more than doubled, and furthermore, the maximum and P90/P10 grew by approximately $150 \%$. The swiftly increasing trend in posttax income may indicate that in addition to an increasing inequality in the pretax income, the redistributive effect of income tax schemes tends to be less progressive.

\section{Results}

\subsection{Basic results}

Insert Table 5 about here 
Table 5 presents the redistributive effects of income tax rates and tax base, evaluated by the RS and the two $\mathrm{BD}$ indices - corresponding to $e=0.25$ and $e=0.75$ - and the reranking effects between 1984 and 2009. In this analysis, each year's tax law is applied to the same year's pretax income, so it is probable that factors other than changes in tax law influence the magnitudes and signs of inequality measures. In the light of the growth rates from 1984 to 2009, in the rightmost column of Table 5, the overall RS index was found to decline by $25 \%$ during the period. We also noted the growth rates in 1984-1989, 1994-1999, and 2004-2009 because there were major income tax reforms for tax rates and deductions in these periods. The growth rates of the RS indices in 1984-1999 and 1994-1999 were negative, but those of 2004-2009 were positive. Explaining this result is difficult because income tax rates and base altered at the same time, and both changes influence tax progressivity. When looking at the redistributive effects of tax rates, they exhibited unexpected results. Throughout the period tax rate effects declined, whereas despite the fact that tax rates in each threshold-including the top tax bracket - decreased in 1984-1989 and 1994-1999, the redistributive effects of tax rates increased during the periods. In contrast, in 2004-2009 tax rate effects dropped with increasing tax rates in every bracket. The redistributive effects of tax base fell in 1984-1989 and 1994-1999, but rose in 2004-2009. This pattern of changes in tax base effect can be explained by the reduced tax bases in the former two periods, and by an increased tax base in the latter. The growth rates of the BD indices are inconsistent with those of the RS indices, sometimes having the opposite sign. From these results, it can be inferred that some parts of the variation in inequality measures result from that in income or different measurement of inequality indices. In other words, redistributive measures aimed at determining the progressivity effects of tax reform may be contaminated by factors other than variation in taxation.

Insert Table 6 about here

We then use the fixed income approach developed by Kasten et al. (1994). Table 6 provides the progressivity measures and trends in tax progressivity between 1984 and 2009, which were calculated by applying 1984-2009 tax laws to 1984 income. The total of each annual inequality index declined gradually until 2004, then increased slightly in 2009. In terms of the 1984-2009 growth rates, the RS indices and the two BD indices have the same signs in every category of measures: negative trends in total and tax base effects and positive trends in rate effects, although the sizes vary. The total effects have 
the same signs as before, but the signs of tax rate and base effects change inversely compared with the estimates in Table 5. For the 1984-1989 and 1994-1999 periods, the overall RS and BD indices declined with changes into lower marginal tax rates, while in 2004-2009 the indices rose for higher or the same tax rates in each income bracket. For 1984-1989 and 1994-1999 the RS and BD indices of tax rate effects increased despite the reduction in marginal tax rates in each income bracket. This result is surprising because lower marginal tax rates in each income bracket are usually expected to yield weaker tax progressivity, or less redistribution for posttax income. As we see later, this counterintuitive result is primarily related to the changes in tax base, which were carried out simultaneously with a reduction in tax rates. In contrast, larger tax deductions and exemptions-yielding a smaller tax base-for 1984-1989 and 1994-1999 reduced the $\mathrm{RS}$ and $\mathrm{BD}$ indices. The findings are intuitive because the equal amounts of shrinking in tax base for all taxpayers yield larger tax burdens for poorer income earners to total income, leading to a more regressive effect of tax base. Further, the reranking effect measures show that total frequency of rerankings decreased but the rerankings for tax base increased. This indicates that from a horizontal equality perspective inequality became less common in total.

Insert Tables 7-11 about here

We next consider the estimation of progressivity measures that are derived from applying 1984-2009 tax laws to an income in the base years-1989, 1994, 1999, 2004, and 2009. Tables 7, 8, 9, 10, and 11 present the results of the inequality measures applied to incomes from 1989, 1994, 1999, 2004, and 2009. As can be seen in Tables $7-$ 11 , for all indices total redistributive effects and tax base effects fell in the period 19842009, while rate effects rose in the same period. This finding means that the redistributive effects of income tax schedule became less effective because of changes in the base effects toward more regressive ones, with tax base shrinking over the period. Regarding the growth of progressivity measures in each period, the RS and both BD indices shown in Tables 7-11 demonstrate that in the periods 1984-1989 and 19941999, the tax rate effects improved after major marginal tax rate reduction, but the tax base effects worsened after the expansions of tax deductions and exemptions. This surprising finding with respect to rate effects is equal to those in Table 6. Further, the three indices indicate that in 2004-2009 rate effects declined but base effects rose, implying that an increase in tax rates in the term negatively affected the equalizing effects of tax rates, whereas an increased tax base-i.e., reduced tax exemptions- has a 
positive impact on base effects. The result of rate effects is also counterintuitive, although consistent with the results obtained in the previous estimation of this study. The growth rates of reranking effects in these analyses provide evidence of a negative trend in relation to total effects and positive trend in relation to base effects.

In summary, by using the fixed income approach, we found that for all indices the total redistributive effects of Japanese income tax decreased between 1984 and 2009. Moreover, after the tax reforms toward lower marginal tax rates and smaller tax base, the redistributive effects of tax rates increased, but those of tax base declined. This finding concerning rate effects is surprising for the reason that a declining tax rate is expected to lead to weaker redistribution effects of tax rates. In addition, the trends in the RS index and the two BD indices basically reach an identical conclusion among the selected base years of the fixed income approach. This fact could enhance the reliability and robustness of this study, as it is frequently pointed out that the outcomes of inequality measures and their trends vary by selected measures and approaches to determine pretax income (e.g., Lambert and Thorensen, 2009).

It is revealed from this analysis that the tax reforms that lowered income tax rates and, at the same time, increased tax deductions and exemptions reduced rate effects. We next consider why this surprising result is obtained. First, this result is concerned with the uniform reduction of the tax base for all taxpayers, which puts larger tax base reductions on low-income earners with regard to total income, with taxable income distribution being more unequal. Such an unequal distribution then increases the effectiveness of the equalizing effect of tax rates. ${ }^{20}$ Thus, a decreasing tax base arising from expanding tax deductions and exemptions gives rise to stronger redistribution via tax rates. This logic could hold for changes in the Japanese income tax scheme in the periods 1984-1989 and 1994-1999.

Insert Table 12 about here

In addition, in the periods 1984-1989 and 1994-1999, small marginal tax rates for low taxpayers after the tax reforms and those for high taxpayers before the reforms seemed to weaken the regressive impacts of the tax reforms on rate effects. This respect can be found in Table 12, which shows the marginal tax rates in each percentile as 1984-2009

20 This situation can be readily imagined from the fact that a uniform income distribution generates no redistribution, leading to no tax progression even if the tax schedule is progressive. 
tax laws are applied to 1984, 1994, and 2004 incomes. For incomes of every year, in 1984-1989 the marginal tax rates of P10, P25, P50, and P75 fell with large reductions being for lower percentiles. This downward tendency is not prominent for the period 1994-1999. In contrast, despite the reduction of top tax rates from 1984 to 1989, tax rates of P95 did not drop for the 1984 and 2004 incomes, suggesting that a number of high income earners had not faced lower marginal tax rates even after the tax reform. This feature means that the actual progressivity of the 1984 personal income tax was lower than expected for the high statutory tax rates, because these extremely high tax rates were not applied to any income earners. It follows that the large scale tax reforms in the late 1980s possibly did not lessen the redistributive effects of tax rates, but, rather, strengthened its equalizing power. Because the Japanese income tax reforms were aimed at reducing both tax rates and tax base at the same time, vice versa, this argument holds for the tax changes in the periods 1994-1999 and 2004-2009.

\subsection{Transplant-and-compare procedure}

As mentioned in Section 3, the fixed income approach may be inadequate for this analysis. Therefore, we applied the transplant-and-compare (T-C) procedure to the income data for Japanese households, to test the tax progressivity effects and check robustness. Because the inequality measures obtained from applying the fixed income approach seem to demonstrate the almost identical pattern for every year's income, we employed the household income data from 1984, 1994, and 2004. To ensure that the T-C procedure is valid for the current analysis, it must be assumed that pretax income distribution is isoelastic, or has a property of base independence, as in Dandanoni and Lambert (2002) and Lambert and Thorensen (2009). We then assumed that under the assumption of isoelastic property, pretax income distributions differ only in location and scale, or their logarithms differ only by their intercepts and slope parameters. When comparing a base year tax policy with a tax policy at year $t$, we then regress pretax income in the base year $x_{i}^{B}$ on that in the year $t, x_{i}^{t}$ :

$$
\ln x_{i}^{B}=a+b \ln x_{i}^{t}+\epsilon_{i}
$$

where $\epsilon_{i}$ is a random error, and subscript $i$ stands for an index of households who are ordered from the bottom with regard to the pretax income in each sample. According to the empirical approach of Lambert and Thorensen (2009), we evaluated the 
goodness-of-fit of the regression based on a measure of $R^{2}$. If the fit is good, we can transform year $t$ posttax income $y_{i}^{t}$ into base-year-adjusted values of posttax income $\hat{y}_{i}^{t}$, which is calculated by $\exp \left(\hat{a}+\hat{b} \ln y_{i}^{t}\right)$ and where the circumflex symbol denotes estimated or fitted value. Analogous to this procedure, a base-year-adjusted value of taxable income $\hat{z}_{i}^{t}$ in year $t$ is calculated from a year $t$ taxable income $z_{i}^{t}$. By comparing inequality measures that are computed from these transplanted pretax income, taxable income, and posttax income, we again examined redistributive effects of tax rates and tax base.

Insert Tables 13, 14, 15 and 16 about here

Table 13 provides the estimation results of the regressions where logs of the base year-1984, 1994, and 2004—pretax incomes are regressed on every year's pretax income. Less than one-third of $R^{2}$ values for the regressions are above 0.95 , and some of them are below 0.90. Thus, it is noted that for Japanese income data employed here, the $\mathrm{T}-\mathrm{C}$ procedure is not an adequate estimation methodology to compare pretax and posttax incomes relative to the fixed income approach, which contradicts the recommendation of Lambert and Thorensen (2009). Tables 14, 15 and 16 present the results of the T-C procedure for 1984, 1994, and 2004 incomes. In line with the results of the fixed income approach, all the inequality indices demonstrate that overall redistribution effects of the tax policies declined from 1984 to 2009. When looking at variation in the redistribution effects of each period, in 1984-1989 the inequality measures rose, whereas dropped in 1994-1999 and 2004-2009. Moreover, it is inferred from these progressivity measures that in 1984-1989 and 1994-1999, the tax reforms toward less progressive tax rates and lower tax base made the equalizing effects of tax rates intense, but such effects of tax base weak. However, some indices of rate effects and base effects - such as the 1984-1989 growth rate for the BD index with the 1984 base income and the 1994-1999 growth rates for the two BD indices with the 1994 base income-exhibit the opposite signs to the previous ones, thereby implying that the worse fits of the regressions somewhat affect the estimates. It follows that although in the current analysis the T-C procedure is not a better method for comparing progressivity measures of tax reforms than the fixed income approach, we can attain the same pattern of changes in the inequality measures as when the fixed income approach is used. 


\section{Conclusion}

In the 1980s some OECD countries dropped their tax progressivity through tax reforms. When Japan implemented the 1987 and 1989 fundamental tax reforms, the income tax rates - in particular of those in the top income-declined and tax deductions increased. This was aimed at lessening the income tax burdens for the middle income earners. A number of studies associated with redistributive effects of income tax reforms in the OECD countries have been accumulated in recent years (e.g., Bishop et al., 1997; Lambert and Thoresen, 2009; Thoresen, 2004; Thoresen et al., 2011). However, despite the existence of major income tax reforms, few researchers have addressed the equalizing effects of the Japanese tax reforms. Moreover, the focus has rarely been placed on the redistributive effects of income tax rates and tax base.

In this study we therefore attempted to reveal the progressivity effects of the Japanese tax reforms in terms of income tax rates and tax base, using microdata from Japanese households. The data employed here comprise household members' earnings data collected by the NSFIE every 5 years between 1984 and 2009. Tax rate effects and base effects were measured by inequality measures used in the literature: the ReynoldsSmolensky (RS) index, and two types of the Blackorby-Donaldson (BD) indices. To control for exogenous factors to influence inequality measurement, we applied 19842009 income tax laws to a base year's fixed income, according to the fixed income approach. For robustness checks, the transplant-and-compare (T-C) procedure, developed by Dardanoni and Lambert (2002), was also used, where incomes are transplanted from another year income to get rid of any noisy elements. We examined the progressivity of income taxation, by comparing the sizes of overall redistributive effects, rate effects, and base effects in 1984-2009.

We obtained the following three results. First, the total redistributive effects of the Japanese income tax schedule declined between 1984 and 2009. During this period, the redistributive effects of tax rates increased, and those of tax deductions and exemptions decreased. Second, the income tax reforms with reductions in tax rates and in tax base gave rise to greater redistributive effects of tax rates and smaller redistributive effects of tax base. This is a surprising result in that lower tax rates are generally associated with a less progressive tax schedule. This result for rate effects draw from the fact that a shrinking of tax bases brought about more unequal taxable income distribution, with the redistributive effects of tax rates being more progressive. Moreover, it is found that 
actual tax rates for high income earners were not so high, even if the top tax rates are extremely high, because of a thin distribution of high income. Third, progressivity measures showed identical trends over the period under any approach concerned with pretax income definition. Therefore, the analyses of this article seem to be consistent and reliable.

One caveat is that this work covers only the income redistribution arising from changes in income taxation, without taking into account changes in local personal income taxes and social security expenses. In addition, income as defined here does not contain imputed income from housing and interests and dividends owing to difficulty in calculating their accurate values. Because they seem to be associated with the trends in tax progressivity, including these elements in this analysis would provide further contribution to the existing literature. 


\section{References}

Bishop, J. A., K. W. Chow, J. P. Formby, and C.-C. Ho. (1997). “Did Tax Reform Reduce Actual US Progressivity? Evidence from the Taxpayer Compliance Measurement Program,” International Tax and Public Finance, 4, 177-197.

Bishop, J. A., J. P. Formby, and B. Zheng. (1998). “Inference Tests for Gini-Based Tax Progressivity Indexes,” Journal of Business and Economic Statistics, 16, 322330

Cowell, F. A. (2011). Measuring Inequality, Oxford University Press: New York.

Dardanoni, V., and P. J. Lambert (2002). "Progressivity Comparisons," Journal of Public Economics, 86, 99-122.

Fellman, J., M. Jäntti, and P. J. Lambert (1999). "Optimal Tax-Transfer Systems and Redistributive Policy,” Scandinavian Journal of Economics, 101(1), 115-126.

Fukawa T., and T. Oshio (2007). "Income Inequality Trends and Their Challenges to Redistribution Policies in Japan,” Journal of Income Distribution, 16(3-4), 9-30.

Gordon, R. H., and J. B. Slemrod (2000). “Are "Real” Responses to Taxes Simply Income Shifting between Corporate and Personal Tax Bases?” in J. Slemrod (Ed.), Does Atlas Shrug, New York: Russell Sage Foundation, 240-280.

Gottschalk, P., and T. Smeeding (1997). "Cross National Comparisons of Earnings and Income Inequality,” Journal of Economic Literature, 35, 633-686.

Ishi, H. (2000). The Japanese Tax System, Oxford Univ Pr on demand.

Kakwani, N. C. (1977). "Measurement of Tax Progressivity: An International Comparison,” The Economic Journal, 87, 71-80.

Kasten, R., F. Sammartino, and E. Toder (1994). “Trends in Federal Tax Progressivity,” in J. Slemrod (Ed.), Tax Progressivity and Income Inequality, Cambridge University Press.

Kitamura Y., and T. Miyazaki (2012). "Income Inequality and Evaluation of the Redistributive Effects of Taxation: 1984-2004,” Economic Journal, 63(1), 56-69. (in Japanese)

Kitamura Y., and T. Miyazaki (2013). A Micro-data Empirical Study on Tax System Reforms, Iwanami: Tokyo. (in Japanese)

Lambert, P. J. (2001). The Distribution and Redistribution of Income, 3rd edition, Manchester University Press.

Lambert, P. J., and X. Ramos (1997). "Vertical Redistribution and Horizontal Inequity," International Tax and Public Finance, 4, 25-37.

Lambert, P. J., and T. O. Thoresen (2009). "Base Independence in the Analysis of Tax 
Policy Effects: with an Application to Norway 1992-2004,” International Tax and Public Finance, 16, 219-252.

Lambert, P. J. and X. Ramos (2003). "Horizontal Equity and Differences in Income Tax Treatment: A Reconciliation,” Research on Economic Inequality, 10, 45-63.

Ministry of Finance (MOF). (2000). Primary Statistics of Taxation. Organization for Economic Co-operation and Development. (1996). Revenue Statistics of OECD Member Countries, Paris. (in Japanese)

Oshio, T. (2006). "Income Inequality and Redistribution Policies in Japan during the 1980s and 1990s,” Journal of Income Distribution, 15 (Index Issue), 119-146.

Pechman and Okner (1974) Who Bears the Tax Burden? Brookings Institution, Washington DC.

Pfahler, W. (1990). "Redistributive Effect of Income Taxation: Decomposing Tax Base and Tax Rates Effects,” Bulletin of Economic Research 42:2, 3307-3378.

Reynolds, M., and E. Smolensky (1977). Public Expenditures, Taxes, and the Distribution of Income: The United States, Academic Press.

Slemrod, J. B. (1992). "Do Taxes Matter? Lessons from the 1980s," American Economic Review, 82, 250-256.

Slemrod, J. B. (1995). "Income Creation or Income Shifting? Behavioral Responses to the Tax Reform Act of 1986," American Economic Review Papers and Proceedings, 85, 175-180.

Thoresen, T. O. (2004). "Reduced Tax Progressivity in Norway in the Nineties: The Effect from Tax Changes,” International Tax and Public Finance, 11, 487-506.

Thoresen, T. O., E. E. Bo, E. Fjærli, and E. Halvorsen (2011). “A Suggestion for Evaluating the Redistributional Effects of Tax Changes: With an Application to the 2006 Norwegian Tax Reform,” Public Finance Review, 40, 303-338.

Yashio, H. (2006). "The Effects of Changes in Marginal Income Tax Rates on Taxable Income: The Case of Business Incomes,” PRI Discussion Paper Series, (No.05A-04), Ministry of Finance, Policy Research Institute. (in Japanese) 
Table 1. Key Income Tax Deductions and Exemptions, 1984-2009

\begin{tabular}{|c|c|c|c|c|c|c|c|}
\hline & & 1984 & 1989 & 1994 & 1999 & 2004 & 2009 \\
\hline & & \multicolumn{6}{|c|}{ A. Tax Deductions } \\
\hline $\begin{array}{l}\text { Deduction for } \\
\text { life insurance }\end{array}$ & Upper limit & 50 & 50 & 50 & 50 & 50 & 50 \\
\hline $\begin{array}{l}\text { Deduction for } \\
\text { social insurance }\end{array}$ & $\begin{array}{l}\text { Rates of deduction } \\
\text { for premiums }\end{array}$ & $100 \%$ & $100 \%$ & $100 \%$ & $100 \%$ & $100 \%$ & $100 \%$ \\
\hline \multirow[t]{2}{*}{$\begin{array}{l}\text { Deduction for } \\
\text { medical expenses }\end{array}$} & Maximum & 2000 & 2000 & 2000 & 2000 & 2000 & 2000 \\
\hline & & \multicolumn{6}{|c|}{ B. Tax Exemptions } \\
\hline Basic exemption & & 330 & 350 & 350 & 380 & 380 & 380 \\
\hline $\begin{array}{l}\text { Exemption for } \\
\text { spouses }\end{array}$ & Maximum & 330 & 350 & 350 & 380 & 380 & 380 \\
\hline $\begin{array}{l}\text { Special } \\
\text { exemption for }\end{array}$ & $\begin{array}{l}\text { Maximum, for } \\
\text { qualified spouse } \\
\text { for exemption }\end{array}$ & - & 350 & 350 & 380 & - & - \\
\hline spouses & $\begin{array}{l}\text { Maximum, for not } \\
\text { qualified spouse }\end{array}$ & - & 350 & 350 & 380 & 380 & 380 \\
\hline $\begin{array}{l}\text { Exemption for } \\
\text { dependents }\end{array}$ & Maximum & 330 & 350 & 350 & 380 & 380 & 380 \\
\hline $\begin{array}{l}\text { Exemption for } \\
\text { the elderly }\end{array}$ & & 250 & 500 & 500 & 500 & 500 & - \\
\hline Total of & & 1240 & 2250 & 2250 & 2400 & 2020 & 1520 \\
\hline
\end{tabular}

Note Unit is thousand yen. One yen is about 0.01 USD. 
Table 2. Descriptive Statistics and Measures of Income Inequality for Pretax Income, 1984-2009

\begin{tabular}{|c|c|c|c|c|c|c|c|}
\hline & 1984 & 1989 & 1994 & 1999 & 2004 & 2009 & $\begin{array}{c}\text { Growth rates, } \\
1984-2009 \\
\end{array}$ \\
\hline \multicolumn{8}{|c|}{ A. Descriptive Statistics } \\
\hline Mean & 236.2 & 231.2 & 235.8 & 235.3 & 232.7 & 233.0 & $-1 \%$ \\
\hline SD & 169.4 & 195.5 & 208.3 & 195.6 & 218.0 & 228.3 & $35 \%$ \\
\hline Minimum & 0 & 0 & 0 & 0 & 0 & 0 & $0 \%$ \\
\hline Maximum & 7829.5 & 9550.5 & 11411.0 & 6800.4 & 8101.5 & 13502.0 & $72 \%$ \\
\hline Observations & 45899 & 52756 & 54182 & 53467 & 50611 & 47084 & $3 \%$ \\
\hline \multicolumn{8}{|c|}{ B. Measures of Income Inequality } \\
\hline Median & 200.9 & 193.8 & 197.6 & 195.7 & 188.8 & 185.0 & $-8 \%$ \\
\hline $\mathrm{CV}$ & 0.717 & 0.845 & 0.883 & 0.831 & 0.936 & 0.980 & $37 \%$ \\
\hline SCV & 0.514 & 0.715 & 0.780 & 0.691 & 0.877 & 0.961 & $87 \%$ \\
\hline Gini & 0.307 & 0.354 & 0.365 & 0.380 & 0.412 & 0.421 & $37 \%$ \\
\hline $\mathrm{TI}$ & 0.173 & 0.236 & 0.250 & 0.260 & 0.310 & 0.323 & $86 \%$ \\
\hline MLD & 0.163 & 0.201 & 0.215 & 0.228 & 0.259 & 0.269 & $65 \%$ \\
\hline \multicolumn{8}{|l|}{ AI } \\
\hline $\mathrm{e}=0.25$ & 0.042 & 0.058 & 0.061 & 0.065 & 0.077 & 0.081 & $94 \%$ \\
\hline $\mathrm{e}=0.75$ & 0.118 & 0.189 & 0.205 & 0.227 & 0.270 & 0.281 & $138 \%$ \\
\hline $\mathrm{P} 10$ & 52.019 & 42.364 & 38.728 & 34.578 & 28.440 & 26.818 & $-48 \%$ \\
\hline P90 & 197.4 & 209.4 & 213.5 & 224.1 & 236.8 & 247.1 & $25 \%$ \\
\hline P90/P10 & 3.795 & 4.943 & 5.512 & 6.480 & 8.325 & 9.214 & $143 \%$ \\
\hline
\end{tabular}

Note : Units of Mean, Minimum, Maximum, and Median are 10 thousand yen, and one yen is about 0.01 USD. SD denotes the standard deviation; CV the coefficient of variation; SVC the squared coefficient of variation; TI the Theil index; MLD the mean logarithmic deviation; AI the Atkinson index. P10 and P90 are proportion of the income at each percentail to the median income. P90/P10 represents the P90 devided by P10. 
Table 3. Descriptive Statistics and Measures of Income Inequality for Taxable Income, 1984-2009

\begin{tabular}{|c|c|c|c|c|c|c|c|}
\hline & 1984 & 1989 & 1994 & 1999 & 2004 & 2009 & $\begin{array}{c}\text { Growth rates, } \\
1984-2009 \\
\end{array}$ \\
\hline \multicolumn{8}{|c|}{ A. Descriptive Statistics } \\
\hline Mean & 150.6 & 142.9 & 158.7 & 148.0 & 152.3 & 154.4 & $2 \%$ \\
\hline SD & 168.7 & 192.9 & 206.3 & 191.7 & 211.9 & 220.0 & $30 \%$ \\
\hline Minimum & 0 & 0 & 0 & 0 & 0 & 0 & $0 \%$ \\
\hline Maximum & 7764.1 & 9458.6 & 11376.4 & 6689.4 & 8047.8 & 13431.4 & $73 \%$ \\
\hline Observations & 45899 & 52756 & 54182 & 53467 & 50611 & 47084 & $3 \%$ \\
\hline \multicolumn{8}{|c|}{ B. Measures of Income Inequality } \\
\hline Median & 113.6 & 99.3 & 115.6 & 100.7 & 99.9 & 97.6 & $-14 \%$ \\
\hline $\mathrm{CV}$ & 1.120 & 1.350 & 1.300 & 1.295 & 1.392 & 1.425 & $27 \%$ \\
\hline SCV & 1.254 & 1.821 & 1.690 & 1.678 & 1.936 & 2.031 & $62 \%$ \\
\hline Gini & 0.473 & 0.543 & 0.520 & 0.566 & 0.581 & 0.575 & $22 \%$ \\
\hline TI & 0.411 & 0.559 & 0.511 & 0.595 & 0.636 & 0.619 & $51 \%$ \\
\hline MLD & 0.318 & 0.296 & 0.283 & 0.258 & 0.266 & 0.302 & $-5 \%$ \\
\hline \multicolumn{8}{|l|}{ AI } \\
\hline $\mathrm{e}=0.25$ & 0.103 & 0.141 & 0.129 & 0.154 & 0.163 & 0.157 & $53 \%$ \\
\hline $\mathrm{e}=0.75$ & 0.368 & 0.528 & 0.492 & 0.599 & 0.621 & 0.584 & $59 \%$ \\
\hline P10 & 14.852 & 0.000 & 0.000 & 0.000 & 0.000 & 0.000 & $-100 \%$ \\
\hline P90 & 273.6 & 314.9 & 293.9 & 342.7 & 355.7 & 371.0 & $36 \%$ \\
\hline P90/P10 & 18.424 & . & . & . & . & . & - \\
\hline
\end{tabular}

Note: The same as Table 2. 
Table 4. Descriptive Statistics and Measures of Income Inequality for Posttax Income, 1984-2009

\begin{tabular}{|c|c|c|c|c|c|c|c|}
\hline & 1984 & 1989 & 1994 & 1999 & 2004 & 2009 & $\begin{array}{c}\text { Growth rates, } \\
1984-2009 \\
\end{array}$ \\
\hline \multicolumn{8}{|c|}{ A. Descriptive Statistics } \\
\hline Mean & 212.7 & 211.2 & 216.6 & 219.0 & 216.1 & 217.4 & $2 \%$ \\
\hline SD & 122.9 & 145.2 & 157.0 & 161.1 & 178.9 & 183.2 & $49 \%$ \\
\hline Minimum & 0 & 0 & 0 & 0 & 0 & 0 & $0 \%$ \\
\hline Maximum & 3376.1 & 5062.9 & 6234.3 & 4457.2 & 5470.6 & 8439.7 & $150 \%$ \\
\hline Observations & 45899 & 52756 & 54182 & 53467 & 50611 & 47084 & $3 \%$ \\
\hline \multicolumn{8}{|c|}{ B. Measures of Income Inequality } \\
\hline Median & 187.6 & 183.6 & 188.0 & 187.7 & 180.9 & 180.2 & $-4 \%$ \\
\hline $\mathrm{CV}$ & 0.578 & 0.687 & 0.725 & 0.735 & 0.828 & 0.843 & $46 \%$ \\
\hline SCV & 0.334 & 0.473 & 0.526 & 0.541 & 0.685 & 0.710 & $113 \%$ \\
\hline Gini & 0.277 & 0.326 & 0.340 & 0.360 & 0.392 & 0.399 & $44 \%$ \\
\hline $\mathrm{TI}$ & 0.135 & 0.191 & 0.208 & 0.229 & 0.274 & 0.282 & $109 \%$ \\
\hline MLD & 0.133 & 0.169 & 0.185 & 0.202 & 0.231 & 0.239 & $79 \%$ \\
\hline \multicolumn{8}{|l|}{ AI } \\
\hline $\mathrm{e}=0.25$ & 0.033 & 0.048 & 0.053 & 0.058 & 0.070 & 0.072 & $118 \%$ \\
\hline $\mathrm{e}=0.75$ & 0.098 & 0.167 & 0.185 & 0.211 & 0.254 & 0.263 & $170 \%$ \\
\hline P10 & 54.547 & 44.379 & 40.351 & 36.017 & 29.366 & 27.531 & $-50 \%$ \\
\hline P90 & 186.0 & 199.3 & 202.6 & 213.8 & 226.2 & 232.1 & $25 \%$ \\
\hline P90/P10 & 3.410 & 4.491 & 5.022 & 5.935 & 7.704 & 8.431 & $147 \%$ \\
\hline
\end{tabular}

Note: The same as Table 2. 
Table 5. Redistributive Effects of Income Tax Rates and Base, 1984-2004

\begin{tabular}{|c|c|c|c|c|c|c|c|c|c|c|}
\hline & 1984 & 1989 & 1994 & 1999 & 2004 & 2009 & $\begin{array}{c}\text { Growth rates, } \\
1984-1989\end{array}$ & $\begin{array}{c}\text { Growth rates, } \\
\text { 1994-1999 }\end{array}$ & $\begin{array}{c}\text { Growth rates, } \\
\text { 2004-2009 }\end{array}$ & $\begin{array}{c}\text { Growth rates, } \\
1984-2009\end{array}$ \\
\hline \multicolumn{11}{|l|}{ RS index } \\
\hline Total & 0.0292 & 0.0280 & 0.0246 & 0.0202 & 0.0197 & 0.0219 & $-4 \%$ & $-18 \%$ & $11 \%$ & $-25 \%$ \\
\hline Rate effects & 0.1952 & 0.2174 & 0.1797 & 0.2061 & 0.1893 & 0.1758 & $11 \%$ & $15 \%$ & $-7 \%$ & $-10 \%$ \\
\hline Base effects & -0.1660 & -0.1894 & -0.1551 & -0.1858 & -0.1695 & -0.1538 & $-14 \%$ & $-20 \%$ & $9 \%$ & $7 \%$ \\
\hline \multicolumn{11}{|c|}{ BD index: e=0.25 } \\
\hline Total & 0.0089 & 0.0103 & 0.0094 & 0.0075 & 0.0082 & 0.0094 & $16 \%$ & $-20 \%$ & $14 \%$ & $6 \%$ \\
\hline Rate effects & 0.0779 & 0.1084 & 0.0882 & 0.1135 & 0.1121 & 0.1013 & $39 \%$ & $29 \%$ & $-10 \%$ & $30 \%$ \\
\hline Base effects & -0.0640 & -0.0885 & -0.0724 & -0.0952 & -0.0934 & -0.0834 & $-38 \%$ & $-31 \%$ & $11 \%$ & $-30 \%$ \\
\hline \multicolumn{11}{|c|}{ BD index: e=0.75 } \\
\hline Total & 0.0236 & 0.0266 & 0.0243 & 0.0205 & 0.0224 & 0.0248 & $13 \%$ & $-16 \%$ & $11 \%$ & $5 \%$ \\
\hline Rate effects & 0.4277 & 0.7655 & 0.6021 & 0.9662 & 0.9669 & 0.7725 & $79 \%$ & $60 \%$ & $-20 \%$ & $81 \%$ \\
\hline Base effects & -0.2831 & -0.4185 & -0.3607 & -0.4810 & -0.4802 & -0.4218 & $-48 \%$ & $-33 \%$ & $12 \%$ & $-49 \%$ \\
\hline \multicolumn{11}{|c|}{ Reranking effects } \\
\hline Total & 0.00010 & 0.00007 & 0.00006 & 0.00005 & 0.00004 & 0.00006 & $-24 \%$ & $-20 \%$ & $35 \%$ & $-40 \%$ \\
\hline Base effects & 0.0046 & 0.0065 & 0.0042 & 0.0062 & 0.0053 & 0.0053 & $41 \%$ & $46 \%$ & $1 \%$ & $15 \%$ \\
\hline
\end{tabular}


Table 6. Redistributive Effects of Income Tax Rates and Base: 1984-2009 Tax Laws Applied to 1984 Incomes

\begin{tabular}{|c|c|c|c|c|c|c|c|c|c|c|}
\hline & 1984 & 1989 & 1994 & 1999 & 2004 & 2009 & $\begin{array}{c}\text { Growth rates, } \\
1984-1989\end{array}$ & $\begin{array}{c}\text { Growth rates, } \\
\text { 1994-1999 }\end{array}$ & $\begin{array}{c}\text { Growth rates, } \\
2004-2009\end{array}$ & $\begin{array}{c}\text { Growth rates, } \\
1984-2009\end{array}$ \\
\hline \multicolumn{11}{|l|}{ RS index } \\
\hline Total & 0.0312 & 0.0262 & 0.0213 & 0.0194 & 0.0182 & 0.0203 & $-16 \%$ & $-9 \%$ & $11 \%$ & $-35 \%$ \\
\hline Rate effects & 0.1613 & 0.2126 & 0.2118 & 0.2533 & 0.1900 & 0.1964 & $32 \%$ & $20 \%$ & $3 \%$ & $22 \%$ \\
\hline Base effects & -0.1301 & -0.1863 & -0.1905 & -0.2339 & -0.1717 & -0.1761 & $-43 \%$ & $-23 \%$ & $-3 \%$ & $-35 \%$ \\
\hline \multicolumn{11}{|c|}{ BD index: $e=0.25$} \\
\hline Total & 0.0094 & 0.0086 & 0.0073 & 0.0066 & 0.0064 & 0.0071 & $-8 \%$ & $-9 \%$ & $12 \%$ & $-24 \%$ \\
\hline Rate effects & 0.0591 & 0.0964 & 0.1004 & 0.1319 & 0.0886 & 0.0923 & $63 \%$ & $31 \%$ & $4 \%$ & $56 \%$ \\
\hline Base effects & -0.0469 & -0.0801 & -0.0846 & -0.1107 & -0.0755 & -0.0780 & $-71 \%$ & $-31 \%$ & $-3 \%$ & $-66 \%$ \\
\hline \multicolumn{11}{|c|}{ BD index: $e=0.75$} \\
\hline Total & 0.0250 & 0.0227 & 0.0191 & 0.0174 & 0.0168 & 0.0183 & $-9 \%$ & $-9 \%$ & $9 \%$ & $-27 \%$ \\
\hline Rate effects & 0.2832 & 0.6476 & 0.7089 & 1.0804 & 0.6046 & 0.6246 & $129 \%$ & $52 \%$ & $3 \%$ & $121 \%$ \\
\hline Base effects & -0.2013 & -0.3793 & -0.4036 & -0.5110 & -0.3663 & -0.3732 & $-88 \%$ & $-27 \%$ & $-2 \%$ & $-85 \%$ \\
\hline \multicolumn{11}{|c|}{ Reranking effects } \\
\hline Total & 0.00012 & 0.00006 & 0.00004 & 0.00004 & 0.00004 & 0.00007 & $-46 \%$ & $-6 \%$ & $65 \%$ & $-43 \%$ \\
\hline Base effects & 0.0028 & 0.0047 & 0.0046 & 0.0073 & 0.0061 & 0.0084 & $67 \%$ & $58 \%$ & $38 \%$ & $194 \%$ \\
\hline
\end{tabular}

Note: The same as Table 5. 
Table 7. Redistributive Effects of Income Tax Rates and Base: 1984-2009 Tax Laws Applied to 1989 Incomes

\begin{tabular}{|c|c|c|c|c|c|c|c|c|c|c|}
\hline & 1984 & 1989 & 1994 & 1999 & 2004 & 2009 & $\begin{array}{c}\text { Growth rates, } \\
\text { 1984-1989 }\end{array}$ & $\begin{array}{c}\text { Growth rates, } \\
1994-1999\end{array}$ & $\begin{array}{c}\text { Growth rates, } \\
\text { 2004-2009 }\end{array}$ & $\begin{array}{c}\text { Growth rates, } \\
1984-2009\end{array}$ \\
\hline \multicolumn{11}{|l|}{ RS index } \\
\hline Total & 0.0322 & 0.0286 & 0.0209 & 0.0188 & 0.0193 & 0.0234 & $-11 \%$ & $-10 \%$ & $21 \%$ & $-27 \%$ \\
\hline Rate effects & 0.1472 & 0.2112 & 0.2779 & 0.3158 & 0.1846 & 0.1810 & $44 \%$ & $14 \%$ & $-2 \%$ & $23 \%$ \\
\hline Base effects & -0.1149 & -0.1826 & -0.2571 & -0.2970 & -0.1653 & -0.1576 & $-59 \%$ & $-16 \%$ & $5 \%$ & $-37 \%$ \\
\hline \multicolumn{11}{|c|}{ BD index: $\mathrm{e}=0.25$} \\
\hline Total & 0.0106 & 0.0104 & 0.0082 & 0.0074 & 0.0075 & 0.0089 & $-2 \%$ & $-10 \%$ & $18 \%$ & $-16 \%$ \\
\hline Rate effects & 0.0556 & 0.1035 & 0.1651 & 0.2060 & 0.0923 & 0.0869 & $86 \%$ & $25 \%$ & $-6 \%$ & $56 \%$ \\
\hline Base effects & -0.0426 & -0.0844 & -0.1346 & -0.1647 & -0.0776 & -0.0717 & $-98 \%$ & $-22 \%$ & $8 \%$ & $-68 \%$ \\
\hline \multicolumn{11}{|c|}{ BD index: $\mathrm{e}=0.75$} \\
\hline Total & 0.0276 & 0.0270 & 0.0206 & 0.0185 & 0.0194 & 0.0226 & $-2 \%$ & $-10 \%$ & $17 \%$ & $-18 \%$ \\
\hline Rate effects & 0.2595 & 0.7142 & 1.5013 & 2.2566 & 0.6447 & 0.5564 & $175 \%$ & $50 \%$ & $-14 \%$ & $114 \%$ \\
\hline Base effects & -0.1842 & -0.4009 & -0.5920 & -0.6873 & -0.3802 & -0.3430 & $-118 \%$ & $-16 \%$ & $10 \%$ & $-86 \%$ \\
\hline \multicolumn{11}{|c|}{ Reranking effects } \\
\hline Total & 0.00017 & 0.00008 & 0.00011 & 0.00009 & 0.00005 & 0.00006 & $-53 \%$ & $-13 \%$ & $22 \%$ & $-62 \%$ \\
\hline Base effects & 0.0044 & 0.0061 & 0.0243 & 0.0285 & 0.0081 & 0.0071 & $39 \%$ & $17 \%$ & $-13 \%$ & $61 \%$ \\
\hline
\end{tabular}

Note: The same as Table 5. 
Table 8. Redistributive Effects of Income Tax Rates and Base: 1984-2009 Tax Laws Applied to 1994 Incomes

\begin{tabular}{|c|c|c|c|c|c|c|c|c|c|c|}
\hline & 1984 & 1989 & 1994 & 1999 & 2004 & 2009 & $\begin{array}{c}\text { Growth rates, } \\
1984-1989\end{array}$ & $\begin{array}{c}\text { Growth rates, } \\
\text { 1994-1999 }\end{array}$ & $\begin{array}{c}\text { Growth rates, } \\
\text { 2004-2009 }\end{array}$ & $\begin{array}{c}\text { Growth rates, } \\
1984-2009\end{array}$ \\
\hline \multicolumn{11}{|l|}{ RS index } \\
\hline Total & 0.0321 & 0.0252 & 0.0222 & 0.0199 & 0.0171 & 0.0221 & $-21 \%$ & $-10 \%$ & $29 \%$ & $-31 \%$ \\
\hline Rate effects & 0.1404 & 0.3106 & 0.2084 & 0.2400 & 0.3104 & 0.1829 & $121 \%$ & $15 \%$ & $-41 \%$ & $30 \%$ \\
\hline Base effects & -0.1083 & -0.2854 & -0.1862 & -0.2201 & -0.2932 & -0.1607 & $-164 \%$ & $-18 \%$ & $45 \%$ & $-48 \%$ \\
\hline \multicolumn{11}{|c|}{ BD index: $\mathrm{e}=0.25$} \\
\hline Total & 0.0107 & 0.0097 & 0.0088 & 0.0078 & 0.0071 & 0.0086 & $-9 \%$ & $-11 \%$ & $22 \%$ & $-19 \%$ \\
\hline Rate effects & 0.0526 & 0.1977 & 0.1119 & 0.1380 & 0.2099 & 0.0908 & $276 \%$ & $23 \%$ & $-57 \%$ & $73 \%$ \\
\hline Base effects & -0.0398 & -0.1570 & -0.0927 & -0.1144 & -0.1676 & -0.0753 & $-294 \%$ & $-23 \%$ & $55 \%$ & $-89 \%$ \\
\hline \multicolumn{11}{|c|}{ BD index: $\mathrm{e}=0.75$} \\
\hline Total & 0.0276 & 0.0244 & 0.0225 & 0.0201 & 0.0176 & 0.0218 & $-12 \%$ & $-11 \%$ & $24 \%$ & $-21 \%$ \\
\hline Rate effects & 0.2437 & 2.1573 & 0.8782 & 1.2240 & 2.3535 & 0.6028 & $785 \%$ & $39 \%$ & $-74 \%$ & $147 \%$ \\
\hline Base effects & -0.1738 & -0.6755 & -0.4556 & -0.5413 & -0.6966 & -0.3625 & $-289 \%$ & $-19 \%$ & $48 \%$ & $-109 \%$ \\
\hline \multicolumn{11}{|c|}{ Reranking effects } \\
\hline Total & 0.00015 & 0.00007 & 0.00005 & 0.00005 & 0.00011 & 0.00007 & $-50 \%$ & $0 \%$ & $-32 \%$ & $-51 \%$ \\
\hline Base effects & 0.0032 & 0.0111 & 0.0060 & 0.0092 & 0.0336 & 0.0095 & $245 \%$ & $54 \%$ & $-72 \%$ & $194 \%$ \\
\hline
\end{tabular}

Note: The same as Table 5. 
Table 9. Redistributive Effects of Income Tax Rates and Base: 1984-2009 Tax Laws Applied to 1999 Incomes

\begin{tabular}{|c|c|c|c|c|c|c|c|c|c|c|}
\hline & 1984 & 1989 & 1994 & 1999 & 2004 & 2009 & $\begin{array}{c}\text { Growth rates, } \\
1984-1989\end{array}$ & $\begin{array}{c}\text { Growth rates, } \\
\text { 1994-1999 }\end{array}$ & $\begin{array}{c}\text { Growth rates, } \\
2004-2009\end{array}$ & $\begin{array}{c}\text { Growth rates, } \\
1984-2009\end{array}$ \\
\hline \multicolumn{11}{|l|}{ RS index } \\
\hline Total & 0.0298 & 0.0236 & 0.0208 & 0.0188 & 0.0160 & 0.0214 & $-21 \%$ & $-10 \%$ & $34 \%$ & $-28 \%$ \\
\hline Rate effects & 0.1284 & 0.2897 & 0.2011 & 0.2280 & 0.3020 & 0.1680 & $126 \%$ & $13 \%$ & $-44 \%$ & $31 \%$ \\
\hline Base effects & -0.0987 & -0.2661 & -0.1803 & -0.2092 & -0.2861 & -0.1467 & $-170 \%$ & $-16 \%$ & $49 \%$ & $-49 \%$ \\
\hline \multicolumn{11}{|c|}{ BD index: $e=0.25$} \\
\hline Total & 0.0091 & 0.0087 & 0.0079 & 0.0071 & 0.0063 & 0.0079 & $-5 \%$ & $-10 \%$ & $25 \%$ & $-13 \%$ \\
\hline Rate effects & 0.0463 & 0.1861 & 0.1127 & 0.1353 & 0.2124 & 0.0832 & $302 \%$ & $20 \%$ & $-61 \%$ & $80 \%$ \\
\hline Base effects & -0.0355 & -0.1496 & -0.0942 & -0.1129 & -0.1699 & -0.0695 & $-321 \%$ & $-20 \%$ & $59 \%$ & $-96 \%$ \\
\hline \multicolumn{11}{|c|}{ BD index: $e=0.75$} \\
\hline Total & 0.0249 & 0.0231 & 0.0216 & 0.0194 & 0.0166 & 0.0212 & $-7 \%$ & $-10 \%$ & $28 \%$ & $-15 \%$ \\
\hline Rate effects & 0.2201 & 2.1890 & 0.9896 & 1.3090 & 2.7085 & 0.5670 & $894 \%$ & $32 \%$ & $-79 \%$ & $158 \%$ \\
\hline Base effects & -0.1600 & -0.6792 & -0.4865 & -0.5585 & -0.7259 & -0.3483 & $-325 \%$ & $-15 \%$ & $52 \%$ & $-118 \%$ \\
\hline \multicolumn{11}{|c|}{ Reranking effects } \\
\hline Total & 0.00016 & 0.00008 & 0.00005 & 0.00004 & 0.00011 & 0.00008 & $-50 \%$ & $-8 \%$ & $-28 \%$ & $-52 \%$ \\
\hline Base effects & 0.0027 & 0.0106 & 0.0054 & 0.0079 & 0.0315 & 0.0078 & $300 \%$ & $48 \%$ & $-75 \%$ & $193 \%$ \\
\hline
\end{tabular}

Note: The same as Table 5. 
Table 10. Redistributive Effects of Income Tax Rates and Base: 1984-2009 Tax Laws Applied to 2004 Incomes

\begin{tabular}{|c|c|c|c|c|c|c|c|c|c|c|}
\hline & 1984 & 1989 & 1994 & 1999 & 2004 & 2009 & $\begin{array}{c}\text { Growth rates, } \\
\text { 1984-1989 }\end{array}$ & $\begin{array}{c}\text { Growth rates, } \\
1994-1999\end{array}$ & $\begin{array}{l}\text { Growth rates, } \\
\text { 2004-2009 }\end{array}$ & $\begin{array}{c}\text { Growth rates, } \\
1984-2009\end{array}$ \\
\hline \multicolumn{11}{|l|}{ RS index } \\
\hline Total & 0.0318 & 0.0296 & 0.0204 & 0.0184 & 0.0197 & 0.0229 & $-7 \%$ & $-10 \%$ & $16 \%$ & $-28 \%$ \\
\hline Rate effects & 0.1282 & 0.2019 & 0.2755 & 0.2990 & 0.1893 & 0.1646 & $57 \%$ & $9 \%$ & $-13 \%$ & $28 \%$ \\
\hline Base effects & -0.0964 & -0.1723 & -0.2551 & -0.2807 & -0.1695 & -0.1417 & $-79 \%$ & $-10 \%$ & $16 \%$ & $-47 \%$ \\
\hline \multicolumn{11}{|c|}{ BD index: $e=0.25$} \\
\hline Total & 0.0103 & 0.0115 & 0.0086 & 0.0077 & 0.0082 & 0.0092 & $12 \%$ & $-10 \%$ & $12 \%$ & $-10 \%$ \\
\hline Rate effects & 0.0476 & 0.1133 & 0.1965 & 0.2256 & 0.1121 & 0.0865 & $138 \%$ & $15 \%$ & $-23 \%$ & $82 \%$ \\
\hline Base effects & -0.0356 & -0.0914 & -0.1570 & -0.1778 & -0.0934 & -0.0711 & $-157 \%$ & $-13 \%$ & $24 \%$ & $-100 \%$ \\
\hline \multicolumn{11}{|c|}{ BD index: $e=0.75$} \\
\hline Total & 0.0276 & 0.0314 & 0.0226 & 0.0202 & 0.0224 & 0.0244 & $14 \%$ & $-10 \%$ & $9 \%$ & $-12 \%$ \\
\hline Rate effects & 0.2211 & 0.9471 & 2.5403 & 3.2603 & 0.9669 & 0.5925 & $328 \%$ & $28 \%$ & $-39 \%$ & $168 \%$ \\
\hline Base effects & -0.1585 & -0.4703 & -0.7112 & -0.7605 & -0.4802 & -0.3568 & $-197 \%$ & $-7 \%$ & $26 \%$ & $-125 \%$ \\
\hline \multicolumn{11}{|c|}{ Reranking effects } \\
\hline Total & 0.00019 & 0.00009 & 0.00005 & 0.00004 & 0.00004 & 0.00008 & $-55 \%$ & $-17 \%$ & $75 \%$ & $-60 \%$ \\
\hline Base effects & 0.0030 & 0.0049 & 0.0088 & 0.0104 & 0.0053 & 0.0066 & $62 \%$ & $18 \%$ & $25 \%$ & $115 \%$ \\
\hline
\end{tabular}

Note: The same as Table 5. 
Table 11. Redistributive Effects of Income Tax Rates and Base: 1984-2009 Tax Laws Applied to 2009 Incomes

\begin{tabular}{|c|c|c|c|c|c|c|c|c|c|c|}
\hline & 1984 & 1989 & 1994 & 1999 & 2004 & 2009 & $\begin{array}{c}\text { Growth rates, } \\
1984-1989\end{array}$ & $\begin{array}{c}\text { Growth rates, } \\
1994-1999\end{array}$ & $\begin{array}{c}\text { Growth rates, } \\
\text { 2004-2009 }\end{array}$ & $\begin{array}{c}\text { Growth rates, } \\
1984-2009\end{array}$ \\
\hline \multicolumn{11}{|l|}{ RS index } \\
\hline Total & 0.0324 & 0.0303 & 0.0237 & 0.0212 & 0.0206 & 0.0236 & $-7 \%$ & $-11 \%$ & $15 \%$ & $-27 \%$ \\
\hline Rate effects & 0.1233 & 0.2082 & 0.2013 & 0.2205 & 0.1845 & 0.1620 & $69 \%$ & $10 \%$ & $-12 \%$ & $31 \%$ \\
\hline Base effects & -0.0909 & -0.1778 & -0.1776 & -0.1994 & -0.1639 & -0.1384 & $-96 \%$ & $-12 \%$ & $16 \%$ & $-52 \%$ \\
\hline \multicolumn{11}{|c|}{ BD index: $e=0.25$} \\
\hline Total & 0.0105 & 0.0122 & 0.0102 & 0.0091 & 0.0089 & 0.0098 & $16 \%$ & $-11 \%$ & $10 \%$ & $-7 \%$ \\
\hline Rate effects & 0.0451 & 0.1246 & 0.1289 & 0.1472 & 0.1142 & 0.0880 & $176 \%$ & $14 \%$ & $-23 \%$ & $95 \%$ \\
\hline Base effects & -0.0330 & -0.0999 & -0.1052 & -0.1204 & -0.0945 & -0.0719 & $-202 \%$ & $-14 \%$ & $24 \%$ & $-118 \%$ \\
\hline \multicolumn{11}{|c|}{ BD index: $e=0.75$} \\
\hline Total & 0.0281 & 0.0334 & 0.0277 & 0.0247 & 0.0244 & 0.0260 & $19 \%$ & $-11 \%$ & $7 \%$ & $-7 \%$ \\
\hline Rate effects & 0.2045 & 1.1539 & 1.3039 & 1.6044 & 1.0398 & 0.6135 & $464 \%$ & $23 \%$ & $-41 \%$ & $200 \%$ \\
\hline Base effects & -0.1464 & -0.5202 & -0.5540 & -0.6066 & -0.4978 & -0.3641 & $-255 \%$ & $-9 \%$ & $27 \%$ & $-149 \%$ \\
\hline \multicolumn{11}{|c|}{ Reranking effects } \\
\hline Total & 0.00019 & 0.00009 & 0.00005 & 0.00004 & 0.00004 & 0.00007 & $-51 \%$ & $-23 \%$ & $61 \%$ & $-63 \%$ \\
\hline Base effects & 0.0019 & 0.0048 & 0.0045 & 0.0057 & 0.0045 & 0.0044 & $150 \%$ & $28 \%$ & $-1 \%$ & $132 \%$ \\
\hline
\end{tabular}

Note: The same as Table 5. 
Table 12. Marginal Income Tax Rates of Taxpayers in Each Percentile: 1984-2009 Tax Laws Applied to 1984, 1994 and 2004 Incomes

\begin{tabular}{|c|c|c|c|c|c|c|}
\hline \multirow{2}{*}{ Percentile } & \multicolumn{6}{|c|}{ Tax laws } \\
\hline & 1984 & 1989 & 1994 & 1999 & 2004 & 2009 \\
\hline & \multicolumn{6}{|c|}{ A. 1984 Income } \\
\hline P10 & $10 \%$ & $0 \%$ & $0 \%$ & $0 \%$ & $0 \%$ & $0 \%$ \\
\hline P25 & $12 \%$ & $10 \%$ & $8 \%$ & $8 \%$ & $8 \%$ & $5 \%$ \\
\hline P50 & $16 \%$ & $10 \%$ & $8 \%$ & $8 \%$ & $8 \%$ & $5 \%$ \\
\hline P75 & $21 \%$ & $10 \%$ & $8 \%$ & $8 \%$ & $8 \%$ & $10 \%$ \\
\hline P95 & $30 \%$ & $29 \%$ & $24 \%$ & $16 \%$ & $16 \%$ & $20 \%$ \\
\hline \multirow[t]{2}{*}{ Max } & $70 \%$ & $50 \%$ & $50 \%$ & $37 \%$ & $37 \%$ & $40 \%$ \\
\hline & \multicolumn{6}{|c|}{ B. 1994 Income } \\
\hline P10 & $12 \%$ & $0 \%$ & $0 \%$ & $0 \%$ & $0 \%$ & $0 \%$ \\
\hline P25 & $14 \%$ & $0 \%$ & $8 \%$ & $7 \%$ & $0 \%$ & $5 \%$ \\
\hline P50 & $17 \%$ & $8 \%$ & $8 \%$ & $8 \%$ & $6 \%$ & $5 \%$ \\
\hline P75 & $21 \%$ & $8 \%$ & $8 \%$ & $8 \%$ & $7 \%$ & $10 \%$ \\
\hline P95 & $30 \%$ & $18 \%$ & $23 \%$ & $16 \%$ & $15 \%$ & $20 \%$ \\
\hline \multirow[t]{2}{*}{ Max } & $70 \%$ & $50 \%$ & $50 \%$ & $37 \%$ & $37 \%$ & $40 \%$ \\
\hline & \multicolumn{6}{|c|}{ C. 2004 Income } \\
\hline P10 & $11 \%$ & $0 \%$ & $0 \%$ & $0 \%$ & $0 \%$ & $0 \%$ \\
\hline P25 & $14 \%$ & $10 \%$ & $0 \%$ & $0 \%$ & $8 \%$ & $5 \%$ \\
\hline P50 & $17 \%$ & $10 \%$ & $6 \%$ & $6 \%$ & $8 \%$ & $5 \%$ \\
\hline P75 & $21 \%$ & $20 \%$ & $7 \%$ & $7 \%$ & $8 \%$ & $10 \%$ \\
\hline P95 & $30 \%$ & $30 \%$ & $15 \%$ & $15 \%$ & $16 \%$ & $20 \%$ \\
\hline Max & $70 \%$ & $50 \%$ & $50 \%$ & $37 \%$ & $37 \%$ & $40 \%$ \\
\hline
\end{tabular}

Note: Marginal tax rates are listed in percent. "Max" denotes the top tax rates. 
Table 13. Oridnary Least Square Regression Results; Log of Income in 1984, 1994 and 2004 Regressed against Log of Income in 1984-2004

\begin{tabular}{|c|c|c|c|c|c|c|c|}
\hline \multicolumn{2}{|c|}{ Dependent variable } & \multicolumn{6}{|c|}{ Year of data, regressors } \\
\hline & & 1984 & 1989 & 1994 & 1999 & 2004 & 2009 \\
\hline \multirow{3}{*}{$\begin{array}{l}\text { Log of } \\
\text { income } \\
1984\end{array}$} & Slope & 1.000 & $1.123 * * *$ & $1.114^{* * *}$ & $1.042^{* * *}$ & $0.890 * * *$ & $0.619 * * *$ \\
\hline & & - & $(0.002)$ & $(0.002)$ & $(0.002)$ & $(0.001)$ & $(0.001)$ \\
\hline & Adjusted R-square & - & 0.90 & 0.90 & 0.91 & 0.94 & 0.96 \\
\hline \multirow{3}{*}{$\begin{array}{l}\text { Log of } \\
\text { income } \\
1994\end{array}$} & Slope & $0.808 * * *$ & $0.866 * * *$ & 1.000 & $0.802 * * *$ & $0.622 * * *$ & $0.549 * * *$ \\
\hline & & $(0.001)$ & $(0.001)$ & - & $(0.001)$ & $(0.001)$ & $(0.001)$ \\
\hline & Adjusted R-square & 0.90 & 0.95 & - & 0.97 & 0.91 & 0.87 \\
\hline \multirow{3}{*}{$\begin{array}{l}\text { Log of } \\
\text { income } \\
2004\end{array}$} & Slope & $1.053 * * *$ & $1.463 * * *$ & $1.454^{* * *}$ & $1.350 * * *$ & 1.000 & $0.715^{* * *}$ \\
\hline & & $(0.001)$ & $(0.002)$ & $(0.002)$ & $(0.002)$ & - & $(0.001)$ \\
\hline & Adjusted R-square & 0.94 & 0.91 & 0.91 & 0.93 & - & 0.93 \\
\hline
\end{tabular}

Note : Standard errors in parentheses. * significant at $10 \%$; ${ }^{* *}$ significant at $5 \%$; *** significant at $1 \%$. 
Table 14. Redistributive Effects of Income Tax Rates and Base: The 1984-Adjusted Values of Taxable and Post-tax Incomes

\begin{tabular}{|c|c|c|c|c|c|c|c|c|c|c|}
\hline & 1984 & 1989 & 1994 & 1999 & 2004 & 2009 & $\begin{array}{c}\text { Growth rates, } \\
1984-1989\end{array}$ & $\begin{array}{c}\text { Growth rates, } \\
1994-1999\end{array}$ & $\begin{array}{c}\text { Growth rates, } \\
2004-2009\end{array}$ & $\begin{array}{c}\text { Growth rates, } \\
1984-2009\end{array}$ \\
\hline \multicolumn{11}{|l|}{ RS index } \\
\hline Total & 0.0292 & 0.0347 & 0.0303 & 0.0227 & 0.0185 & 0.0129 & $19 \%$ & $-25 \%$ & $-30 \%$ & $-56 \%$ \\
\hline Rate effects & 0.1952 & 0.2161 & 0.1712 & 0.2011 & 0.1929 & 0.1602 & $11 \%$ & $17 \%$ & $-17 \%$ & $-18 \%$ \\
\hline Base effects & -0.1660 & -0.1814 & -0.1409 & -0.1784 & -0.1744 & -0.1474 & $-9 \%$ & $-27 \%$ & $16 \%$ & $11 \%$ \\
\hline \multicolumn{11}{|c|}{ BD index: $\mathrm{e}=0.25$} \\
\hline Total & 0.0089 & 0.0134 & 0.0118 & 0.0076 & 0.0059 & 0.0030 & $50 \%$ & $-36 \%$ & $-50 \%$ & $-67 \%$ \\
\hline Rate effects & 0.0779 & 0.0945 & 0.0686 & 0.0860 & 0.0845 & 0.0547 & $21 \%$ & $25 \%$ & $-35 \%$ & $-30 \%$ \\
\hline Base effects & -0.0640 & -0.0741 & -0.0532 & -0.0722 & -0.0725 & -0.0491 & $-16 \%$ & $-36 \%$ & $32 \%$ & $23 \%$ \\
\hline \multicolumn{11}{|c|}{ BD index: $\mathrm{e}=0.75$} \\
\hline Total & 0.0236 & 0.0323 & 0.0282 & 0.0197 & 0.0158 & 0.0084 & $37 \%$ & $-30 \%$ & $-46 \%$ & $-64 \%$ \\
\hline Rate effects & 0.4277 & 0.3451 & 0.2231 & 0.3724 & 0.4086 & 0.2352 & $-19 \%$ & $67 \%$ & $-42 \%$ & $-45 \%$ \\
\hline Base effects & -0.2831 & -0.2325 & -0.1593 & -0.2570 & -0.2789 & -0.1836 & $18 \%$ & $-61 \%$ & $34 \%$ & $35 \%$ \\
\hline \multicolumn{11}{|c|}{ Reranking effects } \\
\hline Total & 0.00010 & 0.00011 & 0.00011 & 0.00011 & 0.00011 & 0.00009 & $14 \%$ & $0 \%$ & $-19 \%$ & $-9 \%$ \\
\hline Base effects & 0.0046 & 0.0042 & 0.0040 & 0.0047 & 0.0051 & 0.0052 & $-9 \%$ & $18 \%$ & $1 \%$ & $12 \%$ \\
\hline
\end{tabular}

Note: The same as Table 5. 
Table 15. Redistributive Effects of Income Tax Rates and Base: The 1994-Adjusted Values of Taxable and Post-tax Incomes

\begin{tabular}{|c|c|c|c|c|c|c|c|c|c|c|}
\hline & 1984 & 1989 & 1994 & 1999 & 2004 & 2009 & $\begin{array}{c}\text { Growth rates, } \\
1984-1989 \\
\end{array}$ & $\begin{array}{c}\text { Growth rates, } \\
1994-1999\end{array}$ & $\begin{array}{c}\text { Growth rates, } \\
2004-2009\end{array}$ & $\begin{array}{c}\text { Growth rates, } \\
1984-2009\end{array}$ \\
\hline \multicolumn{11}{|l|}{ RS index } \\
\hline Total & 0.0222 & 0.0227 & 0.0246 & 0.0158 & 0.0112 & 0.0107 & $2 \%$ & $-36 \%$ & $-5 \%$ & $-52 \%$ \\
\hline Rate effects & 0.1721 & 0.2002 & 0.1797 & 0.1967 & 0.1630 & 0.1450 & $16 \%$ & $9 \%$ & $-11 \%$ & $-16 \%$ \\
\hline Base effects & -0.1499 & -0.1775 & -0.1551 & -0.1809 & -0.1517 & -0.1343 & $-18 \%$ & $-17 \%$ & $12 \%$ & $10 \%$ \\
\hline \multicolumn{11}{|c|}{ BD index: $\mathrm{e}=0.25$} \\
\hline Total & 0.0052 & 0.0071 & 0.0094 & 0.0045 & 0.0029 & 0.0023 & $37 \%$ & $-52 \%$ & $-21 \%$ & $-56 \%$ \\
\hline Rate effects & 0.0547 & 0.0849 & 0.0882 & 0.0848 & 0.0619 & 0.0457 & $55 \%$ & $-4 \%$ & $-26 \%$ & $-16 \%$ \\
\hline Base effects & -0.0469 & -0.0717 & -0.0724 & -0.0740 & -0.0555 & -0.0416 & $-53 \%$ & $-2 \%$ & $25 \%$ & $11 \%$ \\
\hline \multicolumn{11}{|c|}{ BD index: $\mathrm{e}=0.75$} \\
\hline Total & 0.0142 & 0.0194 & 0.0243 & 0.0129 & 0.0091 & 0.0067 & $36 \%$ & $-47 \%$ & $-25 \%$ & $-53 \%$ \\
\hline Rate effects & 0.2259 & 0.3859 & 0.6021 & 0.4128 & 0.2578 & 0.1823 & $71 \%$ & $-31 \%$ & $-29 \%$ & $-19 \%$ \\
\hline Base effects & -0.1727 & -0.2644 & -0.3607 & -0.2831 & -0.1977 & -0.1485 & $-53 \%$ & $22 \%$ & $25 \%$ & $14 \%$ \\
\hline \multicolumn{11}{|c|}{ Reranking effects } \\
\hline Total & 0.00052 & 0.00005 & 0.00006 & 0.00005 & 0.00005 & 0.00017 & $-90 \%$ & $-13 \%$ & $251 \%$ & $-66 \%$ \\
\hline Base effects & -0.0023 & 0.0044 & 0.0042 & 0.0047 & 0.0049 & -0.0021 & $292 \%$ & $11 \%$ & $-144 \%$ & $7 \%$ \\
\hline
\end{tabular}

Note: The same as Table 5. 
Table 16. Redistributive Effects of Income Tax Rates and Base: The 2004-Adjusted Values of Taxable and Post-tax Incomes

\begin{tabular}{|c|c|c|c|c|c|c|c|c|c|c|}
\hline & 1984 & 1989 & 1994 & 1999 & 2004 & 2009 & $\begin{array}{c}\text { Growth rates, } \\
1984-1989\end{array}$ & $\begin{array}{c}\text { Growth rates, } \\
1994-1999\end{array}$ & $\begin{array}{c}\text { Growth rates, } \\
2004-2009\end{array}$ & $\begin{array}{c}\text { Growth rates, } \\
1984-2009\end{array}$ \\
\hline \multicolumn{11}{|l|}{ RS index } \\
\hline Total & 0.0308 & 0.0492 & 0.0440 & 0.0299 & 0.0197 & 0.0146 & $60 \%$ & $-32 \%$ & $-26 \%$ & $-53 \%$ \\
\hline Rate effects & 0.1958 & 0.2392 & 0.2012 & 0.2123 & 0.1893 & 0.1598 & $22 \%$ & $5 \%$ & $-16 \%$ & $-18 \%$ \\
\hline Base effects & -0.1651 & -0.1900 & -0.1572 & -0.1823 & -0.1695 & -0.1452 & $-15 \%$ & $-16 \%$ & $14 \%$ & $12 \%$ \\
\hline \multicolumn{11}{|c|}{ BD index: $\mathrm{e}=0.25$} \\
\hline Total & 0.0102 & 0.0316 & 0.0292 & 0.0162 & 0.0082 & 0.0042 & $210 \%$ & $-45 \%$ & $-49 \%$ & $-59 \%$ \\
\hline Rate effects & 0.0818 & 0.1828 & 0.1450 & 0.1464 & 0.1121 & 0.0643 & $123 \%$ & $1 \%$ & $-43 \%$ & $-21 \%$ \\
\hline Base effects & -0.0662 & -0.1278 & -0.1011 & -0.1136 & -0.0934 & -0.0565 & $-93 \%$ & $-12 \%$ & $40 \%$ & $15 \%$ \\
\hline \multicolumn{11}{|c|}{ BD index: $\mathrm{e}=0.75$} \\
\hline Total & 0.0269 & 0.0727 & 0.0653 & 0.0409 & 0.0224 & 0.0120 & $170 \%$ & $-37 \%$ & $-47 \%$ & $-56 \%$ \\
\hline Rate effects & 0.3532 & 0.8785 & 0.6183 & 0.8262 & 0.9669 & 0.2818 & $149 \%$ & $34 \%$ & $-71 \%$ & $-20 \%$ \\
\hline Base effects & -0.2411 & -0.4289 & -0.3417 & -0.4300 & -0.4802 & -0.2105 & $-78 \%$ & $-26 \%$ & $56 \%$ & $13 \%$ \\
\hline \multicolumn{11}{|c|}{ Reranking effects } \\
\hline Total & 0.00004 & 0.00005 & 0.00005 & 0.00005 & 0.00004 & 0.00004 & $25 \%$ & $-1 \%$ & $-10 \%$ & $-4 \%$ \\
\hline Base effects & 0.0045 & 0.0038 & 0.0038 & 0.0044 & 0.0053 & 0.0060 & $-15 \%$ & $15 \%$ & $14 \%$ & $32 \%$ \\
\hline
\end{tabular}

Note: The same as Table 5. 
Figure 1. Statutory Income Tax Rates against Taxable Income: 1984-2009

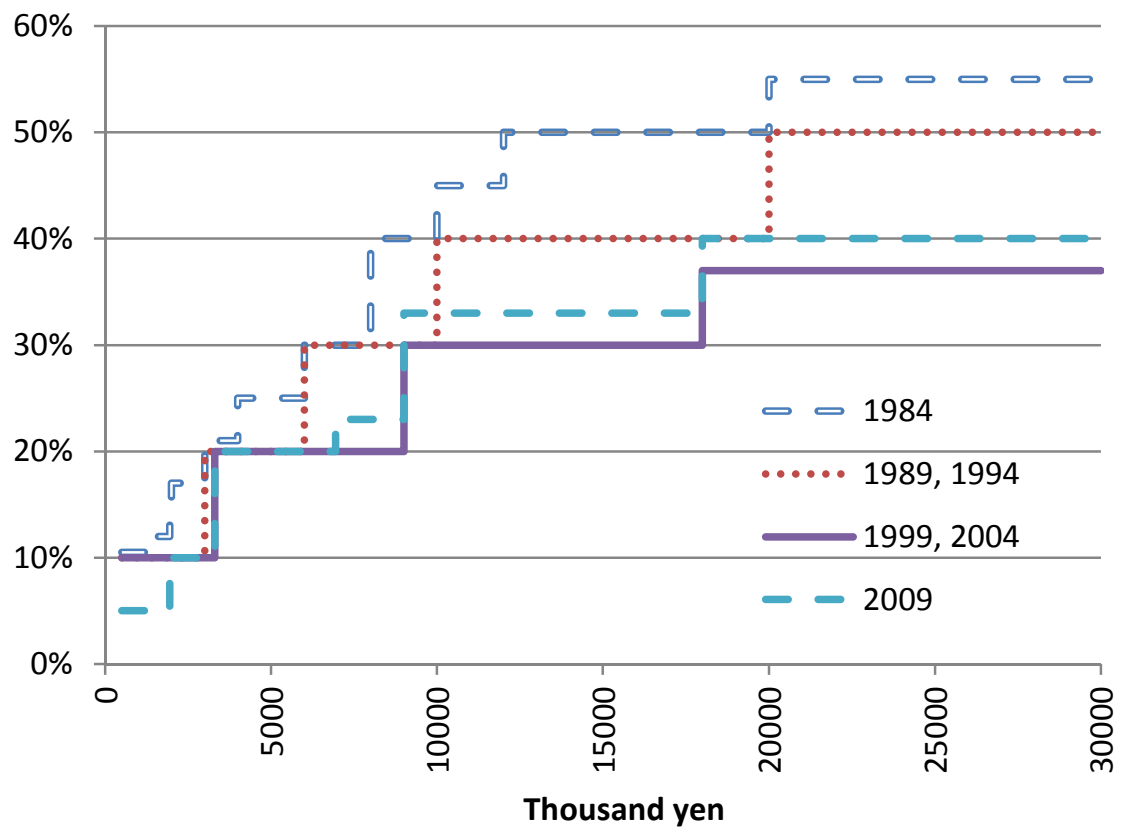

Note: One yen is equal to about 0.01 USD. 